FIDYA FARIDAH KULTSUM DAN ERLINA WIYANARTI

DINAMIKA INGGRIS DAN UNI EROPA: INTEGRASI HINGGA BREXIT

\title{
DINAMIKA INGGRIS DAN UNI EROPA: INTEGRASI HINGGA BREXIT
}

\author{
Oleh: \\ Fidya Faridah Kultsum dan Erlina Wiyanarti ${ }^{1}$
}

\begin{abstract}
Britain is a country that has a great history and influence in the history of other countries, both in economics, military, politics and it can be said that it was ' $a$ compulsion' integration with the European Union. UK and EU relations did not always go smoothly. A lot of dynamics have occurred since the British joined in 1973 until the 2016 referendum decision was issued. The researchers' interest in elaborating the phenomenon was outlined in a historical study of the dynamics between Britain and the European Union since integration until the Brexit decision. Especially to understand the process of British integration, the characteristics of the United Kingdom as a member and the support of the majority of Britains to decide Brexit.
\end{abstract}

Keywords: Brexit, Economic Integration, European Union

\section{PENDAHULUAN}

Pada pertengahan tahun 2016 seluruh media dunia tertuju pada referendum yang diadakan untuk masyarakat Inggris mengenai status keanggotaannya di Uni Eropa. Masyarakat Inggris terpecah menjadi dua golongan dimana terdapat golongan yang merasa Inggris perlu menghentikan kerjasamanya dengan Uni Eropa. Dalam partai politik Inggris golongan ini diwakili oleh partai konservatif yang tokoh pentingnya yakni Boris Johnson. Beliau adalah salah satu politikus yang sering berkampanye untuk Inggris keluar dari Uni Eropa. Sedangkan di golongan yang berlainan adalah dari partai buruh, tokoh pentingnya yakni Jeremy Corbyn. Hingga pada 23 Juni 2016 diadakannya referendrum untuk rakyat
Inggris perihal Brexit ini. Tanggal 24 Juni 2016 hasil referendum keluar, dimana mayoritas masyarakat Inggris memilih untuk keluar dari Uni Eropa (Immanuel \& Wahyudi, 2016, hlm. 177-179). Perihal Brexit ini bukan perkara yang mudah bagi kedua belah pihak. Keduanya harus menyelesaikan urusan-urusan perpisahan dengan waktu yang tidak cepat.

Pada awal integrasinya perjalanan Inggris menuju Uni Eropa tidak mudah, hal ini menjadi menarik dibahas dalam penelitian sejarah untuk mengetahui bagaimana hubungan Inggris dan Uni Eropa di masa lalu. Brexit menjadi sebuah akibat dari sebab-sebab yang terjadi di masa lalu tentunya. Inggris dan Uni Eropa sering memiliki pandangan yang berbeda melihat bahwa Inggris merupakan negara

${ }^{1}$ Fidya Faridah adalah mahasiswa pada Departemen Pendidikan Sejarah FPIPS UPI, Erlina Wiyanarti adalah dosen pembimbing I. Penulis dapat dihubungi di alamat email : email fisoed77@ gmail.com 
memiliki sejarah yang besar, perekonomian yang baik, militer yang kuat, koloni yang banyak dan pada masa sebelumnya sangat enggan untuk menggabungkan diri dengan Eropa daratan. Sehingga seolah Inggris terkesan setengah hati memutuskan bergabung dengan Uni Eropa. Terlihat pada akhirnya, setelah Inggris menjadi anggota Uni Eropa Inggris selalu memiliki pandangan berbeda. Terlebih lagi Inggris dua kali mengadakan referendum hingga pada tahun 2016 referendrum Inggris menghasilkan Inggris keluar dari Uni Eropa yang populer dikenal dengan Brexit (Britain Exit).

Revolusi Industri yang terjadi di Inggris sekitar tahun 1870 menunjukan bahwa Inggris merupakan pencetus perekonomian modern. Selain itu revolusi Industri juga mendorong Inggris untuk menjelajah dunia luar dan melakukan penjajahan (Djaja, 2012, hlm. 139-140). Imperialisasi dan kolonialisasi yang dilakukan bangsa Inggris begitu luas hingga hampir ke seluruh benua di dunia yakni Amerika, Asia, Afrika, dan Australia. Sehingga Inggris memiliki julukan negeri dimana matahari tidak pernah tenggelam. Bahasa Inggris pun hingga hari ini menjadi bahasa pergaulan dunia. Memiliki koloni yang banyak mencirikan inggris dapat dikatakan unggul dalam bidang militer dan perekonomiannya.

Seperti negara-negara lainnya baik yang menang atau kalah perang Inggris memiliki dampak atas perang tersebut, salah satunya di bidang ekonomi. Pasca Perang Dunia II menyadarkan bahwa Inggris membutuhkan Eropa untuk memulihkan kembali perekonomiannya. Masalah yang dihadapi Inggris terkait modernisasi dalam bidang industri dan infrastruktur, penyesuaian cara-cara kerja dengan teknologi modern, yang kemudian mengarahkan Inggris kepada pilihannya tergabung ke dalam pasaran bersama Eropa sebagai langkah yang penting ke arah integrasi European Free Trade Area (EFTA) dan European Economic Community (EEC) (Luhulima, 1992, hlm.46). Kerajaan Inggris Raya adalah pionir, baik dalam kolonialisasi, industri, pemimpin dalam perekonomian dunia dan memiliki tanggung jawab untuk 'mengajari' dunia sesuai dengan pengalaman nasionalnya. Kemudian secara intitusional Inggris juga tidak pernah mengalami keruntuhan institusi seperti negara lain dalam kedua Perang Dunia. Hal ini kemudian mempengaruhi Inggris memandang dirinya dalam hubungan Internasional.

Dinamika terus terjadi selama keanggotaan Inggris dengan Uni Eropa, terkait dengan kebijakan dan lain sebagainya. Hingga pada akhirnya sikap skeptis Inggris menyebar luar ke masyarakat Inggris, yang kemudian menjadi dukungan mayoritas masyarakat Inggris terhadap Brexit. Pada awalnya referendum hanyalah sebuah ancaman bagi Uni Eropa agar dapat tetap menerima Inggris yang tetap berada di luar Eropa. Namun ketika masyarakat Inggris memilih 'Brexit' pemerintah Inggris tidak bisa berkutik, dan melanjutkan proses pemisahan. Representatif masyarakat Inggris menunjukan fenomena populisme, yakni melihat bahwa politik merupakan ekspresi dari rakyat kebanyakan (Perdana, 2017, hlm. 2). Adapun pertentangan kultur yang terjadi antara imigran dan penduduk asli Inggris yang menguatkan fenomena populisme ini. Sehingga dukungan terhadap partai yang anti Uni Eropa semakin menguat. Seperti yang dituliskan 


\section{FIDYA FARIDAH KULTSUM DAN ERLINA WIYANARTI DINAMIKA INGGRIS DAN UNI EROPA: INTEGRASI HINGGA BREXIT}

dalam jurnal Contemporary Far Right Racist Populism in Europe bahwa penyatuan kebijakan bagi kebanyakan orang (seperti yang dilakukan Uni Eropa) bukan menjadi solusi dan menimbulkan masalah (Vieten \& Poynting, 2016, hlm. 5), dalam hal ini untuk negara yang berkebangsaan besar seperti Inggris.

Oleh karena itu dalam penelitian ini penulis merumuskannya dalam empat rumusan masalah. Pertama, mengenai latar belakang integrasi Inggris ke Uni Eropa. Kedua, mengenai proses integrasi Inggris ke Uni Eropa. Ketiga, mengenai sikap politik Inggris ketika menjadi anggota Uni Eropa. Dan keempat, mengenai alasan mayoritas warga Inggris memilih Brexit.

\section{METODE PENELITIAN}

Penelitian ini menggunakan metode penelitian historis dengan langkahlangkah sebagai berikut. Pertama, heuristik adalah mencari, menemukan dan mengumpulkan data dan fakta dari berbagai sumber baik berupa buku-buku maupun artikel mengenai dinamika integrasi Inggris dan Uni Eropa sampai Brexit tahun 1973-2016. Dalam tahap heuristik peneliti mencari sumber, berupa sumber literatur. Teknik studi literatur ini digunakan untuk mengumpulkan sumbersumber atau tulisan yang dianggap relevan dan menjawab permasalahan yang akan dibahas yaitu mengenai "Dinamika Inggris dan Uni Eropa: Integrasi hingga Brexit(1973-2016)". Sumber-sumber tertulis yang digunakan penulis sebagai referensi diperoleh dari beberapa tempat, diantaranya, Perpustakaan Universitas Pendidikan Indonesia (UPI), Perpustakaan Institut Teknolgi Bandung (ITB), dan Perpustakaan Universitas Indonesia, adapun e-book yang banyak penulis temukan mengenai hubungan Inggris dan Uni Eropa, selain itu juga terdapat kutipan dari berbagai media, baik dalam negeri maupun luar negeri.

Kedua, kritik sumber, setelah penulis mendapatkan berbagai sumber yang dianggap relevan dengan permasalahan yang dikaji, tahap selanjutnya adalah penulis melakukan penilaian dengan mengkritik sumber-sumber yang telah ditemukan tersebut baik dari buku, browsing internet, sumber tertulis dan hasil dari penelitian serta sumber lainnya. Dalam melakukan penelitian ini penulis tidak melakukan kritik eksternal karena sumber yang penulis gunakan berupa sumber sekunder. Kritik internal yang dilakukan penulis yakni ketika penulis mendapatkan sumber. Penulis membaca isi sumber kemudian dibandingkan dengan sumber lain yang juga dibaca penulis. Hasil perbandingan sumber tersebut, akan diperoleh kepastian bahwa sumber tersebut bisa digunakan karena sesuai dengan topik dan kajian.

Ketiga, interpretasi atau yang biasa disebut dengan analisis sejarah merupakan tahap dimana peneliti melakukan sintesis atas sejumlah fakta yang diperoleh dari sumber-sumber sejarah dan bersamasama dengan teori-teori disusunlah faktu itu ke dalam suatu interpretasi yang menyeluruh. Dalam kaitannya dengan penelitian skripsi yang berjudul "Dinamika Inggris dan Uni Eropa: Integrasi hingga Brexit (1973-2016)". Interpretasi yang penulis lakukan adalah terhadap datadata dan fakta-fakta yang ditemukan. Sehingga penafsiran tersebut dapat dipertanggungjawabkan oleh penulis. Penulis menafsirkan bahwa kebutuhan 
ekonomi akan selalu berhubungan dengan hubungan internasional atau regional suatu negara dengan negara lainnya. Terlebih lagi hubungan ekonomi tersebut kemudian akan diikuti oleh hubungan politik yang akan mengikat hubungan tersebut. Hal ini ditunjukan oleh Inggris, yang pada awalnya merupakan sebuah negara yang berjaya di luar pulau Eropa dengan koloni hampir di seluruh benua di dunia, yang tidak akan pernah memilih Eropa daratan. Namun saat ekonomi yang mendesaknya, Inggris bergabung dengan Uni Eropa yang terkesan memaksakan diri. Dan kemudian setelah bergabung selama empat puluh tahun, ketika Inggris tidak dapat menyelesaikan masalahnya dengan Uni Eropa, ia memutuskan untuk keluar. Dalam penelitian ini merujuk pada sumber-sumber yang penulis temukan. Penulis akan memberikan interpretasi dalam pembahsannya.

Keempat, historiografi merupakan proses penyusunan hasil interpretasi dalam bentuk tulisan yang utuh di dalam sebuah skripsi yang berjudul "Dinamika Inggris dan Uni Eropa Integrasi hingga Brexit 1973-2016". Penggunaan metode historis dalam penelitian didukung juga dengan penggunaan pendekatan interdisipliner, hal ini sebagai alat bantu dalam menganalisis suatu permasalahan.

\section{PEMBAHASAN}

Brexit merupakan keputusan masyarakat Inggris untuk meninggalkan Uni Eropa yang dicanangkan oleh David Cameron sejak masa kampanyenya tahun 2016. Referendum dilaksanakan pada tahun 2016 yang hasilnya mayoritas warga Inggris memilih Brexit yakni sebanyak $52 \%$. Sangat tipis sekali perbedaannya yang memilih untuk tetap tinggal dan untuk keluar. Keputusan tersebut tentu bukan terjadi begitu saja, jauh sebelum tahun 2016, sejak integrasinya dengan Uni Eropa hubungannya tidak berjalan mulus. Tahun 1973 merupakan diputuskannya Inggris menjadi anggota Uni Eropa dalam "Accession of Britain in the European Community" ditandatangani pada 22 Januari 1972.

Latar belakang bergabungnya Inggris ke Uni Eropa tidak terlepas dari alasan ekonomi dan politik. Runtuhnya imperium dan hilangnya kekuasaan Inggris di dunia Internasional sejak 1939-1945 menyadarkan Inggris bahwa Inggris harus lebih memperhatikan masalah-masalah dalam negerinya dan menyelesaikannya. Wilayah pertahanan Inggris di Asia Tenggara terkait dengan kerjasamanya dengan Amerika untuk membendung kekuatan komunis menjadi beban ekonomi Inggris, yang tidak sesuai dengan kemampuan ekonomi Inggris. Pangkalan militer Inggris di Aden yang berkekuatan 14.000 orang memerlukan $\$ 168$ juta setahunnya; pangkalan Singapura dan Malaysia yang berkekuatan 51.000 orang memerlukan \$630 juta, sedangkan di Hongkong dengan kekuatan 7.000 orang menelan \$42 juta setahun (Luhulima, 1992, hlm. 48-49). Biaya yang Inggris keluarkan untuk pengamanan di wilayah Asia Tenggara membuat Inggris mengalami kerugian. Sedangkan sebenarnya Inggris sendiri perlu memperhatikan urusan ekonomi dalam negerinya yang terkena dampak setelah perang dunia. Setelah negarajajahannya merdeka, pasokanbahan mentah Inggris juga berkurang. Walaupun begitu dalam hal ini Inggris masih dapat mengandalkan Amerika Serikat, dan 
FIDYA FARIDAH KULTSUM DAN ERLINA WIYANARTI

DINAMIKA INGGRIS DAN UNI EROPA: INTEGRASI HINGGA BREXIT

negara-negara Persemakmuran yang masih dapat bekerjasama dengan mudah. Sehingga ada yang disebut dengan "three centre circles" atau tiga lingkaran utama dalam perekonomian Inggris.

Perubahan orientasi ekonomi luar negeri Inggris bukan saja karena masalah tarif, adapun masalah lainnya mengenai kekuatan ekspor. Faktor ini kemudian menjadi salah satu yang mempertimbangkan Inggris untuk menentukan keanggotaannya di Uni Eropa. Pada awalnya pusat utama dalam lingkaran ekonomi Inggris adalah negaranegara Persemakmuran, dimana ekspor Inggris kepada negara-negara tersebut mencapai 50\% hingga pada tahun 1950. Perdagangan di wilayah Sterling ini diyakini dapat memulihkan perekonomian Inggris pasca perang. Terutama kepada negara Australia dan Selandia Baru, Inggris merupakan pasar ekspor paling penting. Hal ini karena negara Persemakmuran memasukan hasil pertaniannya tanpa tarif dan tanpa batasan kuantitatif, sedangkan dengan negara Eropa masih ada pembatasan kuantitatif. Selain pada negara Persemakmuran pasca Perang Dunia II orientasi politik dan ekonomi Inggris berpihak kepada Amerika Serikat. Amerika Serikat muncul sebagai negara kreditur terbesar di dunia. Halini dilakukan Amerika karena ketakutan pihak komunis akan mempengaruhi negara-negara yang ketakutan. Dalam hubungannya dengan Amerika Serikat, Inggris harus mendukung proyek Amerika Serikat dalam sistem perdagangan multilateral dengan konversi mata uang. Ini berarti Inggris harus menerima Bretton Woods Agreement dan setuju untuk pengenalan konvertibilitas Sterling di pertengahan
1947. Hingga munculnya permasalahan yakni AS berhenti memberikan pinjaman dan negosiasi juga sulit. Penghentian proyek nuklir Manhattan antara AS dan Inggris membuat Inggris terpaksa mengembangkan penghalang nuklir dengan biaya sendiri, yang membutuhkan biaya cukup besar. Inggris mendapati ekspor yang menurun pada tahun 1950an, yakni dari $25,5 \%$. Pada tahun 1960 porsi ekspor ke negara persemakmuran tenggelam sedangkan ke Eropa Barat meningkat $19,6 \%$.

Keputusan Inggris menjadi anggota Masyarakat Ekonomi Eropa (sebelum Uni Eropa) adalah karena kemajuan organisasi tersebut dengan diberlakukan bebas pajak antar negara anggota. Hal ini membuat industri Inggris merasa kalah saing jika ia tidak bergabung dengan MEE. Hal tersebut bersamaan dengan makin berkurangnya pengaruh Inggris terhadap negaranegara Persemakmuran tempat barangbarang Inggris dijual. Oleh karena itu pada tahun 1961 pengajuan permohonan bergabungnya Inggris ke Masyarakat Ekonomi Eropa diumumkan oleh Harold Macmillan yang pada saat itu merupakan Perdana Menteri dan pemimpin pemerintahan Partai Konservatif.

Proses pengajuan diri Inggris bergabung dengan masyarakat Eropa tidak berlangsung dengan mudah. Inggris mendapatkan dua kali veto Prancis yakni pada tahun 1962, hal ini berkaitan dengan hubungan antara keduanya di masa lalu. Pada tahun 1944 Perdana Menteri Inggris Chruchill mengatakan kepada Presiden Prancis De Gaulle "Whenever we have to choose between Europe and the open sea, we shall always choose the open sea. Whenever I have to choose between you and 
Roosevelt, I shall always choose Roosevelt" (Lee, 2007, hlm. .200). Veto de Gaulle juga diakibatkan karena ketakutan Prancis bahwa Inggris merupakan jembatan antara Eropa dan Amerika Serikat. Dan jika memang itu benar De Gaulle berasumsi bahwa Amerika Serikat akan mengambil alih Eropa, sehingga pengaruh Prancis di Eropa akan diambil juga. Permasalahan tersebut berakhir ketika Presiden Prancis diganti oleh Georges Popidou pada tahun 1969.

Selanjutnya permasalahan masuknya Inggris ke Uni Eropa adalah mengenai kebijakan pertanian. Dimana Inggris bukan negara yang mengutamakan pertanian seperti Prancis dan Jerman. Inggris mengimpor hasil pertanian dari negara-negara persemakmuran. Kebijakan tersebut dirasa kurang relevan dengan Inggris. Masalah pertanian ini masih sulit diatasi, walaupun memiliki posisi yang penting. Terlihat bagaimana MEE masih belum berhasil menentukan hargaharga pertanian bersama (Common Farm Pricse/CAP). Secara umum MEE ingin pendapatan sektor pertanian dapat sebanding dengan pendapatan di sektorsektor ekonomi lainnya.

Mengenai hubungan Inggris dengan AmerikaSerikatyangdisebutAngloAmerika juga menjadi masalah. Hubungan Inggris dan AS adalah sebagaimana hubungannya dengan negara-negara Persemakmuran yang berdaulat, terlebih yang dengan negara-negara yang penduduknya berasal dari Eropa. Hubungan itu bersumber dari kesamaan ras, kesamaan warisan spiritual dan bahasa, serta sejak 1918 sampai 1945 sebagai aliansi militer. Dalam suatu tindakan politik hingga klimaksnya pada bencana Terusan Suez tahun 1956, mempertanyakan kekhawatirannya kepada Kennedy, perihal keanggotaan Inggris dalam Masyarakat Eropa apakah tidak akan membahayakan "hubungan khusus" Anglo Amerika, namun Kennedy tidak mengerti akan hal itu.

Seiring berjalannya waktu Inggris dapat melewati kesulitan-kesulitannya. Dalam laporan internal di kantor luar negeri "Accession of Britain in the European Community" menunjukan komponen utama keberhasilan dalam negosiasi bukan rincian teknis tetapi lingkungan eksternal yang menguntungkan (yakni pensiun dan meninggalnya de Gaulle). Dan yang paling penting adalah kemenengan partai Konservatif pada pemilu. Dengan bergabung dengan Masyarakat Eropa, Inggris harus meninggalkan peran independennya di dunia dan asumsi hakhak serta kewajiban konsekuensi sebagai anggota EC sebagai fakta yang jelas sejak 1970 (Sorokina, 2014, hlm. 19).

Kemudian setelah menjadi anggota, karakter Inggris dipengaruhi oleh Perdana Menteri yang menjabat, dan kebijakan atau keputusan yang diambil dalam menjalin hubungan dengan Uni Eropa. Awal keanggotannya (pada masa E. Heath 1970-1974), Inggris cenderung menyetujui kebijakan Uni Eropa. Walaupun sebenarnya masih ada permasalahan-permasalahan yang terjadi akibat belum selesainya penyesuaian sebelum keanggotaan. Hubungan baik tersebut dilimpahkan kepada pemerintah selanjutnya yang justru bertolak belakang.

Pada pemerintahan Thatcher Inggris dibawa ke sikap skeptis. Hal ini karena adanya ketidaksesuain kebijakan Uni Eropa terhadap Inggris, terutama masalah kesatuan moneter dan finansial, dimana 


\section{FIDYA FARIDAH KULTSUM DAN ERLINA WIYANARTI \\ DINAMIKA INGGRIS DAN UNI EROPA: INTEGRASI HINGGA BREXIT}

Uni Eropa akan membentuk suatu kesatuan moneter dengan bank sentral dan mata uang tunggal. Selain itu juga terkait masalah anggaran Inggris untuk ME yang dirasa cukup besar dan harus dikurangi. Inggris pada akhir 1970-an Inggris adalah kontributor kedua terbesar dan akan menjadi yang terbesar. Yakni membayar lebih dari 1 milyar Euro pertahun (Wall, 2008, hlm. 20).

Pandangan Inggris terhadap ME condong kepada pasar bebas, yang menguntungkan perekonomian Inggris, Inggris seperti tidak peduli bahwa, pada dasarnya ME ini dibuat adalah untuk sebuah integrasi yang lebih jauh lagi dari hanya pada sektor ekonomi yakni politik. Adapun kemudian politisasi ekonomi yang tidak disetujui Inggris. Thatcher tidak mengingankan adanya penyatuan moneter dan finansial. Inggris menginginkan pasar tunggal Eropa dengan penghapusan hambatan pergerakan barang, pembentukan pasar bebas, asuransi dan modal, yang akan menguntungkan perusahaan-perusahaan Inggris. Prancis dan Jerman sebagai negara inti dari Uni Eropa tidak ingin Inggris dapat mempengaruhi anggota lain terhadap kebijakan yang akan ditetapkan oleh Uni Eropa. Bagi Thatcher kesatuan moneter dan pembentukan Bank Sentral nantinya akan membuat suatu pemerintah Eropa. Dan bahwa kesatuan moneter dapat terlaksana tanpa mata uang tunggal. Perdana Menteri selanjutnya John Mayor dan Tony Blair juga tetap berada diluar European Moneter Union (EMU).

Pada periode selanjutnya yakni pemerintahan John Mayor (1990-1997) yakni dalam Perjanjian Maastritcht permasalahan Inggris masih berkutat dalam EMU. Sehingga Inggris dalam proses tanda tangan dalam perjanjian Maastritcht, bersikeras mengadopsi protokol tersebut, yang memungkinkan Britania tidak berpartisipasi dalam tahap ketiga pembentukan EMU (Sorokina, 2012, hlm. 38-39). Hal ini kemudian membuat Inggris memiliki hak untuk tetap keluar dari penciptaan kesatuan ekonomi dan moneter, hingga dalam kondisi yang memungkinkan untuk melakukan pengenalan mata uang tunggal.

Inggris tidak menandatangani bab mengenai "Social Chapter of Treaty" dalam Perjanjian Maastritcht, dimana Bab Sosial yakni menyatakan aturan umum hubungan industrial dan kesejahteraan sosial di negara-negara dari Komunitas Eropa. Hal ini karena didukung oleh situasi ekonomi Inggris, yang tingkat inflasinya rendah selama 30 tahun, pengurangan pengangguran, pertumbuhan kegiatan usaha, tingkat bunga bank rendah, serta stabiltasi nilai tukar poundsterling. Sedangkan jika ketentuan-ketentuan dari Piagam berlaku di Inggris menurutnya bisa membahayakan. Dalam hal ini negara akan dipaksa mengambil biaya sosial yang tinggi yang berpengaruh terhadap pekerjaan (sehingga banyak pekerjaan yang ditutup karena tidak sesuai dengan standar Eropa), yang akan berakibat pada peningkatan harga, dan kerusakan daya saing perusahaan Inggris di pasar dunia.

Perdebatan dalam integrasi Inggris pada Uni Eropa khususnya pada masa kepemimpinan M. Thatcher dan John Major, mengenai European Moneter Union (EMU), Bank Sentral Eropa, mata uang tunggal, dan pertentangan Bab Sosial dalam perjanjian Maastricht membuat Inggris menjadi terisolasi dalam 
Uni Eropa. Oleh karena itu Partai Buruh (dengan Tony Blair sebagai Perdana Menteri) mencanangkan untuk "Back to Europe”. Yakni untuk meningkatkan kembali citra Inggris di Uni Eropa. Partai Buruh dan Partai Konservatif pada dasarnya memiliki sikap yang berbeda, namun tetap kepada kepentingan bersama yakni kepentingan Inggris. Namun dalam beberapa hal mereka juga berada di satu jalan. Pemerintahan Inggris oleh Partai Buruh, dipimpin oleh Tony Blair (19972007) bersikeras untuk ikut kembali berpartisipasi pada integrasi Eropa hal ini karena keterasingan Inggris di Uni Eropa menyebabkan lemahnya pengaruh Inggris pada kebijakan Uni Eropa. Jika hal tersebut merupakan alasan Inggris kembali ke Uni Eropa dapat dikatakan, upaya-upaya Blair tersebut kembali kepada pragmatisme Inggris dalam Uni Eropa bukan saja dalam bidang ekonomi namun juga politik.

Pada pemerintahan Partai Konservatif David Cameron harus menghadapi krisis yang terjadi di eurozone atau zona euro ini. Kebangkrutan yang terjadi akibat krisis, bukan hanya pada bank saja, tetapi seluruh negara, terutama Yunani, Spanyol dan Italia. Perbedaan sikap Inggris dalam mengatasi krisis (dengan negara Uni Eropa lain) membuat ketegangan diantara kedua pihak. Pada persiapan KTT darurat, negara-negara eurozone mengungkapkan perbedaan-perbedaan dalam memerangi krisis (Sorokina, 2014, hlm. 70-71). Konselir keuangan G. Osborne pada pertemuan parlemen 11 Agustus, mengusulkan untuk memangkas pengeluaran publik, untuk memungkinkan kestabilan keuangan negara. Usulannya tersebut tentu dengan mempertimbangkan kepentingan Inggris. Inggris dan para negara Uni Eropa lainnya bersama-seama mencari jalan keluar untuk mengatasi krisis. Hal yang ditakutkan Inggris muncul, yakni dominasi PrancisJerman dalam penyelesaian krisis.

Pertemuan di Brussels pada 2326 Oktober 2011 membuat keputusan untuk tidak melibatkan negara-negara yang berada di luar zona Euro dalam penyelesaian krisis. Debat terbuka yang dilakukan oleh David Cameron dan Nicolas Sarkozy pada tanggal 24 Oktober menolak klaim Inggris dalam mengambil bagian dalam pertemuan wakil-wakil dari negaranegara zona Euro. Perdana Menteri Inggris gagal untuk membuat koalisi dari negaranegara di luar zona Euro (Denmark, Hungaria, Bulgaria, Latvia, Lithuania, Polandia, republik Ceko, Rumania, Swedia) walaupun tujuh diantaranya bergabung (Rainey \& Jones, www.telegraph.co.uk, 25 Oktober 2011). Bersikerasnya Inggris adalah karena krisis yang terjadi di zona Euro akan berdampak kepada negaranegara di luar zona Euro. Oleh karena itu, Inggris menuntut dilindunginya kegiatan perusahaan Inggris dan bank terhadap kontrol keuangan dari lembaga Eropa.

Hubungan antara Inggris dan Uni Eropa selama empat puluh tiga tahun sejak bergabungnya tahun 1973 mencapai puncaknya pada tahun 2016. Dinamika yang terjadi diantaranya, membuat hal ini tidak mengejutkan. Seperti yang telah diungkapkan sebelumnya, bahwa naik turunya, dekat jauhnya, Inggris dan Uni Eropa tidak mengherankan jika pada akhirnya keduanya memutuskan untuk berpisah. Hal ini apakah karena Inggris yang memang sejak awal terkesan "setengah hati" dalam integrasi. Terlihat bagaimana Uni Eropa lebih "pengertian" mengenai kebijakan Uni Eropa yang tidak 


\section{FIDYA FARIDAH KULTSUM DAN ERLINA WIYANARTI DINAMIKA INGGRIS DAN UNI EROPA: INTEGRASI HINGGA BREXIT}

diambil Inggris, yang disebut pemberian $j$ status khusus bagi Inggris.

23 Juni 2016 merupakan hari besar bagi masyarakat Inggris, dimana ia melakukan keputusan besar, dan menjadikannya sebagai momentum mengenai hubungannya dengan Uni Eropa. Setelah beberapa tahun mengenai isu referendum Brexit dicanangkan, pada hari itu hasilnya sudah keluar. Dengan hasil 52\% memilih keluar dan $48 \%$ tetap bertahan (CNN, www.cnn.com/euro/eureferendum, 25 Juni 2016). Namun untuk merujuk kepada keluarnya Inggris dari Uni Eropa harus melalui proses yang panjang, setidaknya dua tahun.

Pada saat keputusan rakyat adalah Brexit, yang terjadi kemudian adalah pengunduran diri David Cameron sebagai Perdana Menteri Inggris. Keputusan ini karena David Cameron ingin Inggris tetap berada di Uni Eropa. Kemudian penyelesaian selanjutnya mengenai Brexit akan diteruskan oleh Theresa May yang merupakan Perdana Menteri Inggris yang baru. Keputusan masyarakat Inggris untuk keluar dari Uni Eropa memunculkan fenomena yang disebut populisme.

Populisme adalah suatu pandangan politik yang menempatkan rakyat kebanyakan dan elit yang korup dalam posisi antagonis dan melihat politik sebagai ekspresi dari keinginan umum rakyat kebanyakan (Cas Mudde dalam Perdana, 2017, hlm. 2). Menurut Inglehart dan Norris yang utama terjadi di Inggris bukan soal ekonomi tetapi alasan yang kuat adalah masalah kultur (Inglehart \& Norris, 2016, hlm. 6-7). Kejayaan masa lalu Inggris masih membayangi masyarakat generasi tua, yang kemudian paling banyak mendukung Brexit. Masalah imigirasi juga memberikan gesekan kultural, yang membuat masyarakat (kebanyakan di pedesaan) terganggu dengan imigran yang berasal dari negara lain yang tidak sedikit memiliki bahasa dan unsur budaya lain yang berbeda. Hal ini diawali oleh kemunculan golongan euroskeptis di masyarakat, dan menyebarkan paham skeptis yang membuat masyrakat menjunjung sikap primordialis.

Munculnya golongan Euroskeptis sangat berpengaruh dalam hubungan antara Inggris dan Uni Eropa. Kelompok ini muncul akibat ketidaksetujuannnya Inggris bergabung dengan Uni Eropa. Mereka telah ada pada saat Inggris baru saja bergabung dengan Uni Eropa (yakni diadakannya referendum di parlemen tentang keanggotaan Inggris). Sebagai contoh Partai Buruh mempertahankan keanggotaan UE, seperti Tony Blair yang terus berusaha mendekatkan diri kepada UE untuk kepentingan Inggris. Sedangkan Partai Konservatif tidak setuju akan keanggotaan semenjak Margareth Thatcher dan John Major. Namun dikemudian hari kelompok Euroskeptis muncul dalam tubuh partai lain.

Imigrasi merupakan konsekuensi bagi Inggris ketika dirinya bergabung dengan Uni Eropa. Uni Eropa membebaskan warga negranya untuk berpindah ke negara anggota lainnya termasuk dalam mencari pekerjaan. Ketakutan ini kemudian yang dirasakan oleh warga Inggris. Untuk mengatasilonjakansebenarnyapemerintah Inggris akan membuat pembatasan, namun gagasan tersebut ditentang oleh anggota-anggota Uni Eropa. Hal ini yang menjadikan isu imigrasi diangkat oleh kelompok euroskeptis dalam kampanye Brexit. Karena dampak jangka pendek 
dari imigrasi tersebut dirasakan langsung oleh masyarakat. Partai UKIP (United Kingdom Independent Party) gencar menyuarakan isu imigrasi. Partai tersebut mengkampanyekan mengenai imigrasi di Inggris yang merugikan masyarakat Inggris (Qolbi, 2016, hlm. 58-59).

Dalam setiap kampanyenya kubu Brexit (UKIP atau Boris Johnson) meyakinkan bahwa Brexit memungkinkan untuk lebih mengkontrol banyaknya imigran yang datang ke Inggris dari Uni Eropa. Selama sepuluh tahun (19952015) jumlah imigran dari negara Uni Eropa lainnya yang tinggal di Inggris bertambah tiga kali lipat dari 0,9 juta jiwa menjadi 3,3 juta. Dari angka tersebut 2,5 juta imigran ini berusia 16-64 tahun dan dua juta adalah orang yang bekerja. Selain mengenai pekerjaan alasan lain mengenai pengangkatan isu ini dikalangan masyarakat yang berpendidikan rendah atau para orang tua adalah mengenai budaya dalam masyarakat. Seperti takut orang lain yang memainkan peran penting dan menentukan identitas nasional mereka (Clarke \& Whiteley, 2016, hlm. 6). Walaupun riset lain menunjukan bahwa sebenarnya populasi imigrasi lebih meningkatkan keseluruhan pendapatan nasional, namun tetap hal tersebut mengancam orang-orang Inggris sendiri.

Isu yang paling utama dikalangan pemerintah Inggris yang kemudian nantinya tersampaikan kepada masyarakat lewat kampanye-kampanye para tokoh yakni mengenai kedaulatan Inggris. Penyatuan moneter dengan adanya bank sentral dan penyatuan mata uang. Inggris bersiteguh untuk tetap di luar kebijakan tersebut, karena menurutnya itu sudah mencampuri ranah kedaulatan
Inggris sebagai negara. Kemudian juga dibentuknya konstitusi Eropa dan integrasi militer yang membuat ketegangan antara Inggris dan Uni Eropa semakin terlihat. Uni Eropa dengan kebijakan-kebijkannya banyak mengatur negara-negara bagiannya yang menyinggung masalah kedaulatan negara tersebut.

Merujuk kepada media Inggris yakni The Economist bahwa ada pernyataan mengenai Brexit yakni slogan "Take control" maksudnya adalah bahwa Uni Eropa telah mengambil kontrol atas Inggris, dimana seharusnya Inggris dapat mengkontrol negaranya sendiri. Menurut Michael Gove bahwa hal ini merupakan inti kasus Brexit, beliau menyatakan pendapatnya bahwa keanggotaan Uni Eropa telah menghentikan Inggris untuk memilih siapa yang dapat membuat keputusan penting yang berpengaruh terhadap kehidupan Inggris (The Economist, www.economist.com., 19 Maret 2016). Selanjutnya bahwa argumen mengenai kedaulatan Inggris, yakni keanggotaan Uni Eropa berarti hukum Eropa mengalahkan hukum nasional Inggris. Faktor-faktor tersebut merupakan faktor yang mendukung masyarakat Inggris memilih untuk Brexit. Munculnya kelompok euroskeptis, menyebarkan paham-paham skeptis di masyarakat Inggris yang mengangkat isu-isu yang merugikan Inggris dalam keanggotaannya di Uni Eropa. Paham ini menggiring opini publik dan memunculkan fenomena populisme.

\section{SIMPULAN}

Inggris dalam keanggotaannya dengan Uni Eropa tidaklah mudah, belum lagi Inggris harus menyampingkan sikapnya 


\section{FIDYA FARIDAH KULTSUM DAN ERLINA WIYANARTI \\ DINAMIKA INGGRIS DAN UNI EROPA: INTEGRASI HINGGA BREXIT}

sebagai negara independen yang kemudian 'harus' berintegrasi dengan Uni Eropa karena kebutuhan ekonomi dan politik. Dinamika yang terjadi antara Inggris dan Uni Eropa bukan saja saat mendekati referendum 2016 namun jauh sebelum itu yakni sejak masa bergabungnya. Persiapan-persiapan Inggris menuju Uni Eropa yang belum matang menjadi pemicu permasalahan. Pandangan politik Inggris terhadap Uni Eropa berubah-ubah, seiring dengan pandangan politik Perdana Menterinya. Inggris bersikap skeptis terhadap Uni Eropa diawali oleh Harold Wilson (Partai Buruh), kemudian M. Thatcher (konservatif). Selanjutnya Tony Blair (Partai Buruh) bersikap mendukung Uni Eropa ketika lawannya bersikap skeptis. Hal ini tersebut kemudian membuat Uni Eropa sebagai bahan untuk kampanye tiap partai. Pilihannya tetap di Uni Eropa atau tidak. Juga referendum Brexit menjadi 'senjata' bagi Inggris agar Uni Eropa mau mentoleransi Inggris dalam kebijakannya. Tahun 2016 referendum menyatakan Brexit, yang tidak disangka oleh David Cameroon.

Perluasan kelompok Euroskeptis di masyarakat membuat isu-isu untuk memilih Brexit. Tentang imigrasi yang dianggap sangat merugikan rakyat Inggris. Tentang kedaulatan, dimana Inggris kini tidak berhak atas kedaulatannya sendiri karena segala aturan dikendalikan Brussels. Banyak warga Inggris yang menyetujui Brexit juga karena para pejabat yang berkampanye tidak kemudian menjelaskan positifnya menjadi anggota Uni Eropa. Hal ini dirasakan orangorang Skotlandia dan Irlandia Utara yang lebih memilih Bremain. Bahkan Brexit akan memicu mereka untuk menyatakan referendum keluar dari bagian United Kingdom.

Tidak diherankan jika pandangan politik Inggris sering terlihat naik turun. Terkadang pro dan tetapi ada pula bersikap kontra. Hal demikian terjadi karena sebelumnya Inggris juga merasa enggan masuk ke Eropa karena Inggris dengan sejarahnya yang besar adalah negara yang independen, dalam segala bidang, bahkan negara pencetus revolusi industri yang memiliki pengaruh kepada sistem ekonomi dunia. Kekuatan Inggris pun melebihi kekuasaan Jerman dan Prancis (saingannya sekarang). Kejayaan di masa lalu menjadi bayang-bayang masyarakat Inggris bahwa ia akan kembali berdiri sendiri bahkan menguasai dunia dengan Brexit sebagai langkah awalnya.

\section{DAFTAR PUSTAKA}

Abdurahman, D. (2007). Pengantar Metode Penelitian. Yogyakarta: Kurnia Alam Semesta.

Clarke, D.H, dkk.(tt). Why Britain voted for Brexit:an individual -level analysis of the 2016 referendum vote. [Pdf]. Tersedia di http://blogs.kent. ac.uk/files diakses pada 12 September 2017.

CNN. (2016). Referendum Brexit. [Daring] Tersedia di www.cnn.com/euro/eureferendum diakses pada 12 September 2017.

Davies, N. (2000) The Isles: A history. London: Macmillan.

Djaja, W. (2012). Sejarah Eropa: Dari Eropa Kuno Hingga Eropa Modern. Yogyakarta: Ombak.

Erlanger, S.(2016). 'Brexit' vote feeds Scotland's Alienation.[Daring]. Tersedia di https://mobile.nytimes. com diakses pada 11 September 2017. 
Hyden,S. (2016). Brexit vote in Northern Ireland Brings Uncertainty.[Daring]. Tersedia di http://time.com/world/ NorthernIreland diakses pada 11 September 2017.

Immanuel, P., \& Wahyudi. (2016). Sejarah Uni Eropa: Membedah Masa Lalu dan Isu Terkini. Solo: Azka Pressindo.

Inglehart, R.F., \& Norris, P. (2016). Trump, Brexit and the Rise of Populism: Economic Have-Nots and Cultural Baclash.[Pdf]. Tersedia di http:// research.hks.harvard.edu/getFile diakses pada 30 Maret 2018.

Ismaun (2005). Pengantar Belajar Sejarah sebagai Ilmu dari Wahana Pendidikan. Bandung: Historia Utama Press.

Lee, S. J. (2007). Aspescts of European History 1789-1980. Taylor \& Francis Group. Diakses 7 Juli 2017, dari Taylor \& Francis e-Library.

Luhulima, C. P. F. (1992). Eropa sebagai Kekuatan Dunia: Lintasan Sejarah dan Tantangan Masa Depan. Jakarta: Gramedia.

Perdana, A.A. (2017). Menguatnya Populisme: Trump, Brexit hingga FPI. Tersedia di https://indogopress. com/2017/o1 diakses pada 30 Maret 2018
Qolbi, A. (2016). Alasan Partai United Kingdom Independence Party (UKIP) Menginginkan Inggris Keluar dari Uni Eropa dalam Referendum Inggris 2016. (Skripsi). Universitas Muhammadiyah Yogyakarta, Yogyakarta.

Rainey, S., \& Jones, L. (2011). EU referendum debate: as it happened 24 October. Tersedia di http://www. telegraph.co.uk/news diakses pada 11 Juni 2017.

Sorokina, M. (2014). Great Britain and the European Integration. (Thesis). Masaryk University, Brno.

The Economist. (2016). Dreaming on sovereignity. [Daring]. Tersedia di www.economist.com/britain diakses pada 12 September 2017.

Vieten, U. M., \& Poynting, S. (2016) Contemporery Far-Right Racist Populism in Europe. Journal of Intercultural Studies, Vol.37(6), hlm. 533-540. tersedia di www.tandfonline. com.doi.full diakses pada 30 Maret 2018.

Wall, S. (2008). A Stranger in Europe: Britain and the EU from Thatcher to Blair. Oxford: Oxford University Press. 